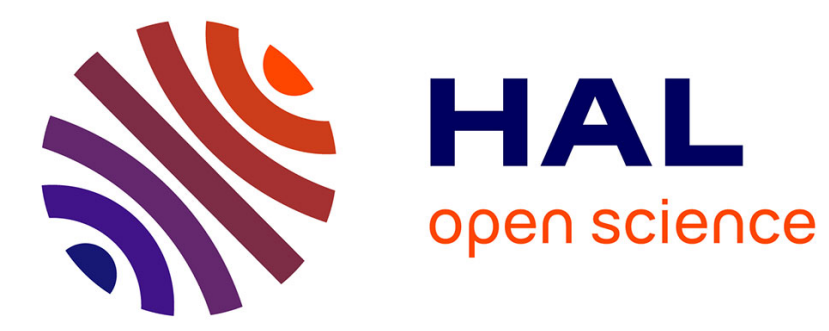

\title{
Integrating multipurpose perennial grains crops in Western European farming systems
}

Olivier Duchene, Florian Celette, Matthew Ryan, Lee R Dehaan, Timothy E Crews, Christophe David

\section{- To cite this version:}

Olivier Duchene, Florian Celette, Matthew Ryan, Lee R Dehaan, Timothy E Crews, et al.. Integrating multipurpose perennial grains crops in Western European farming systems. Agriculture, Ecosystems and Environment, 2019, 10.1016/j.agee.2019.106591 . hal-02894050

\section{HAL Id: hal-02894050 https://hal.science/hal-02894050}

Submitted on 8 Jul 2020

HAL is a multi-disciplinary open access archive for the deposit and dissemination of scientific research documents, whether they are published or not. The documents may come from teaching and research institutions in France or abroad, or from public or private research centers.
L'archive ouverte pluridisciplinaire HAL, est destinée au dépôt et à la diffusion de documents scientifiques de niveau recherche, publiés ou non, émanant des établissements d'enseignement et de recherche français ou étrangers, des laboratoires publics ou privés. 


\title{
Integrating multipurpose perennial grains crops in Western European farming systems
}

Olivier Duchene ${ }^{1 *}$, Florian Celette ${ }^{1}$, Matthew R. Ryan ${ }^{2}$, Lee R. DeHaan ${ }^{3}$, Timothy E. Crews ${ }^{3}$, Christophe David ${ }^{1}$

1. ISARA, Research Unit Agroecology and Environment, 23 Rue Jean Baldassini, 69364 Lyon cedex 07, France

2. Soil and Crop Sciences Section, School of Integrative Plant Science, Bradfield Hall, Cornell University, Ithaca, NY 14853, USA

3. The Land Institute, 2440 E. Water Well Rd., Salina, KS, 67401, USA

* Corresponding author : Phone.: +33 (0)4 278585 65. E-mail: olduchene@ isara.fr

\section{Highlights}

- Challenges in Western European agriculture may be addressed by perennial grain crops

- $\quad$ Perennial traits of intermediate wheatgrass provide ecosystem services

- Improved populations of intermediate wheatgrass are suitable for grain-forage dual use

- $\quad$ Additional grain value could increase profitability of grasslands and mixed farming

\begin{abstract}
Western European agriculture is largely defined by the high level of productivity of its cereal grain production. Such productivity is largely a result of farm specialization and intensification. This approach however has led to environmental problems and farm sensitivity to climatic and economic hazards. Recently, perennial grains have been promoted as a potential alternative, particularly with intermediate wheatgrass (Thinopyrum intermedium). Perennial grains bring new perspectives and innovation, and can contribute to both system diversification and environmental performance. Above all, the value of yearround ground cover and root activity, as well as the ability to harvest both grain and forage production, offers a large range of interest and potential application for such a grain crop. Realization of the potential benefits from perennial grains depends on the development of suitable seed material and the identification of tangible economic and environmental benefits coming from the integration of perennial grains into crop rotations. Although more work is needed, perennial grains are compatible with the current European interests and policies for food security, soil health, water quality, and farmer interest in innovative practices and sustainable cropping systems.
\end{abstract}

Keywords: perennial grains, intermediate wheatgrass, multifunctionality, agroecology, innovation, diversification

\section{Perennial grains: an agroecological innovation for Western Europe?}

Most of the human food supply is provided by annual cereal crops. Western Europe includes some of the most productive regions for cereal grains in the world. With about 30 million hectares that produce more than 40 million tons of grain, France represents the largest country in terms of agricultural area and is the largest producer of small grain cereals (Eurostat, 2018) (Figure 1). Wheat is the most commonly cultivated cereal crop. For example, in France, wheat is grown on $73 \%$ of cropland used for small grain production (Figure 2, red section of the pie 
chart). Average wheat yield is over $7 \mathrm{Mg}$ ha-1 in conventional and $3 \mathrm{Mg}$ ha-1 in organic systems (Agreste, 2018; FranceAgriMer, 2012). Grain farming is characterized by high yields and intensive management. The productivity is facilitated by extensive use of inputs under low-diversity and short term crop rotations (Mudgal et al., 2010). Unfortunately, these crops are widely associated with environmental degradation due to soil disturbance prior to sowing and the fertilizers and pesticides that are applied to support production (Power, 2010). The main ecosystem disservices include soil erosion, nutrient runoff or leaching, pest spread and resistance (pathogens, weed and insects), loss of biodiversity and organic matter depletion (Crews et al., 2016; Crews and Peoples, 2005). Europe loses about 970 million tons of soil per year via soil water erosion, with an average of about $2.5 \mathrm{t}$ ha- $1 \mathrm{yr}-1$ considering the European Union's erosion-prone lands (Panagos et al., 2015). Considering both the mean soil loss rate and the area concerned, France accounts for $11.85 \%$ of the total soil loss, the third highest share in Western Europe (Panagos et al., 2015). Much of the soil lost from agricultural fields ends up in surface waters where it negatively impacts water quality. Pesticides and nutrients can also contaminate surface and ground water. A recent broad assessment in France highlighted that $53 \%$ of surface water has pesticide concentration higher than the European threshold of $0.1 \mathrm{mg} \mathrm{L}-1$, and $43 \%$ of ground water has nitrate concentration higher than the European threshold of $25 \mathrm{mg} \mathrm{L-1}$ (Michon, 2016).

Innovations are needed to overcome tradeoffs between crop production and environmental goals. Adebiyi et al. (2016) termed these innovations "radical transformative technologies" as "their architecture, functionality, component principles and underlying science markedly depart from existing agricultural systems" and suggests perennial grains as one of these "radical transformations". While other regions such as North America and Australia have been conducting research on perennial grain crops for more than a decade, similar research is still rare in Western Europe (Hayes et al., 2018). Recently a research program in France was set up in 2017. 
Figure 1. Total production of small grain cereals (1000 tons) in Western Europe. Circles size and numbers inside indicate the average yield of wheat by country (tons ha-1). Figure created from European online data (Eurostat, 2018).

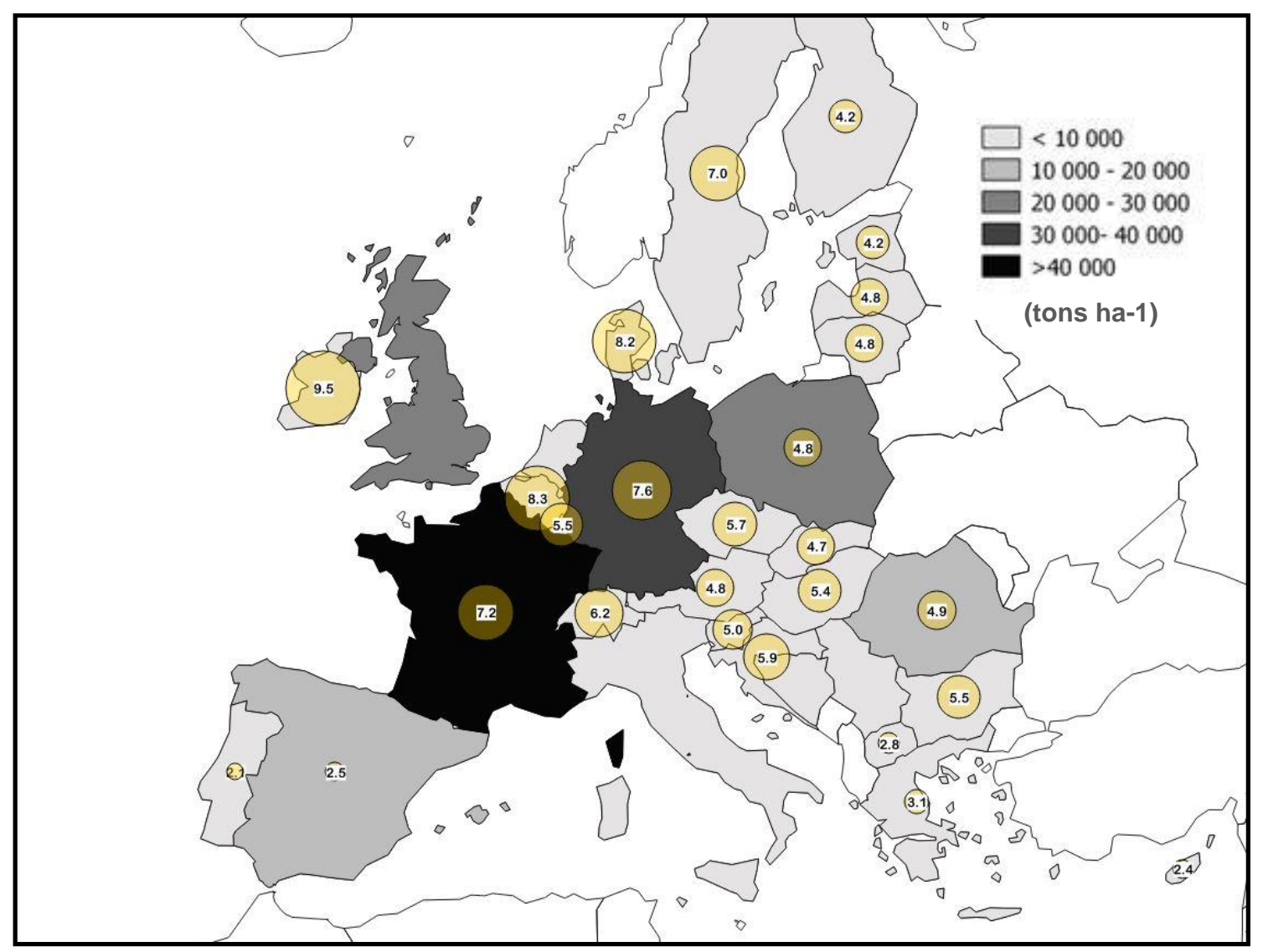

Figure 2. Proportion (\%) of arable lands used for small grain cereal production in Western Europe. Red shares of pie charts indicate the proportion of wheat fields. Figure created from European on line data (Eurostat, 2018).

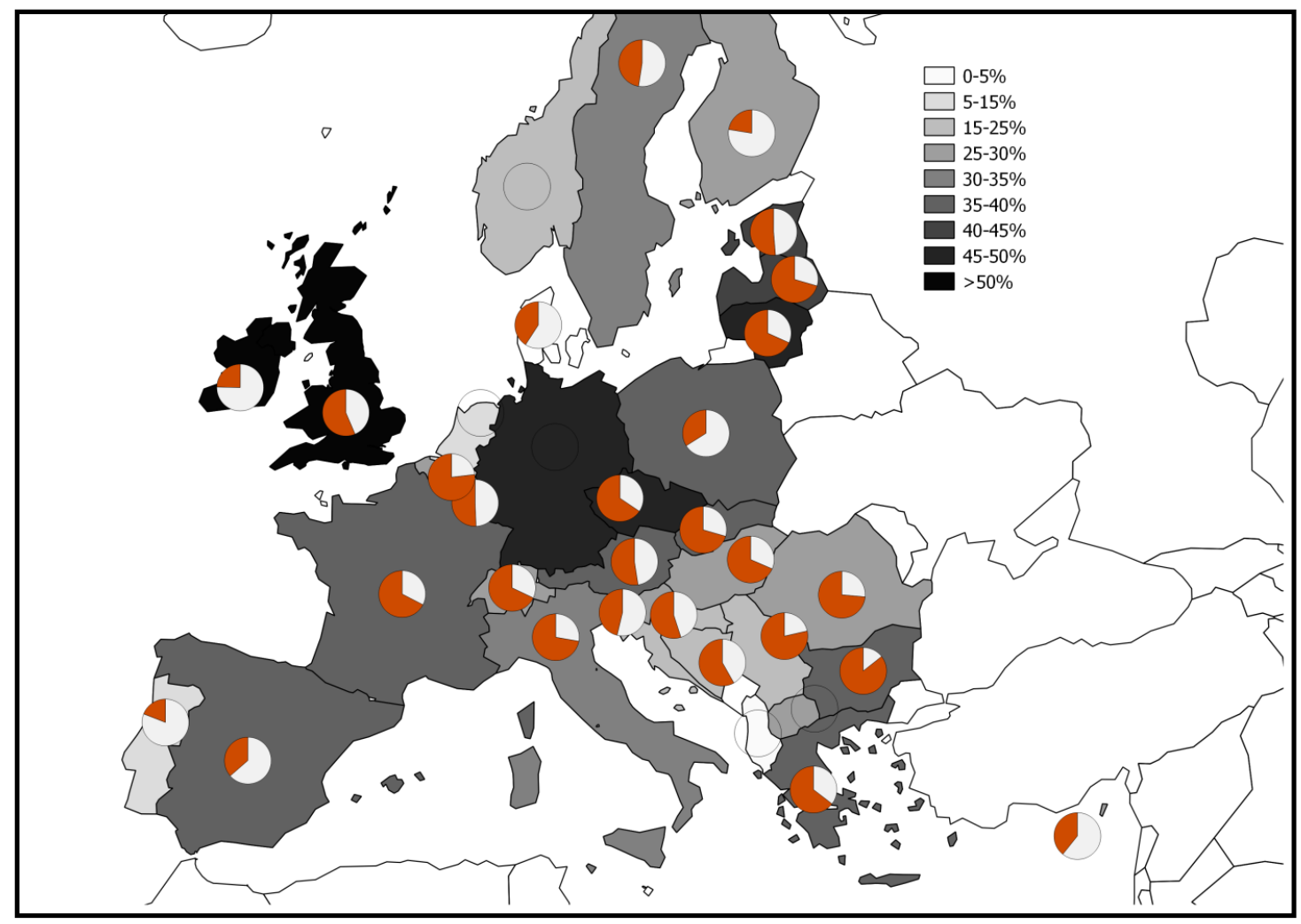


With a dedicated breeding program at The Land Institute (TLI), Kansas, USA, the perennial, wheat-relative, intermediate wheatgrass (IWG), Thinopyrum intermedium, marketed as "Kernza", is a promising deep-rooted forage-grain producing crop (DeHaan and Ismail, 2017). It demonstrates good longevity and high biomass production along with significant grain yields compared to other perennial grasses (DeHaan et al., 2005). Kernza ${ }^{\circledR}$ is already being used as an ingredient in US food products, and as such IWG is the most documented perennial grain prototype and presents a unique opportunity to discuss the potential of perennial grains in the Western European farming context. This review used the available literature published after 2000. Papers were targeted using the scientific search engines Web of Science, Google Scholar and Science Direct, and were found through using "perennial grain", "perennial crop", "Kernza", "Intermediate wheatgrass", "Thinopyrum intermedium", "perennial wheat" and "perennial grass" as keywords. Complementary and related papers were then used to support discussion (e.g. the European agricultural context; the development of organic, conservation or agroecological practices; nature and importance of grassland services).

Figure 3. Grain-forage biomass production of IWG at the spring growth peak (photo 1, June 15, 2018, field experiment in Southern France), and at early post-harvest regrowth (photo 3, September 13, 2018, same field experiment). IWG head before flowering period (photo 2)
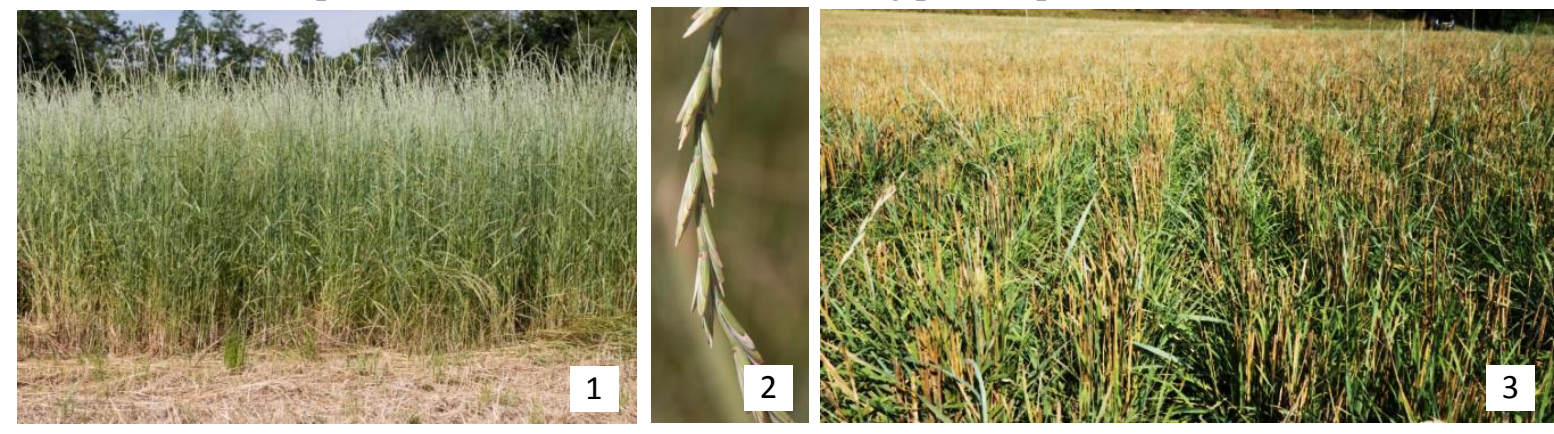

\section{Perennial grain: potential to provide ecosystem services for Western Europe}

Although current breeding efforts are promising and suggest further yield improvements will be forthcoming, IWG is currently unable to compete with annual counterparts in terms of grain productivity, mainly due to low harvest index which is around 0.10 (Culman et al., 2013; DeHaan et al., 2018). In contrast, perennial grain accessions obtained from the hybridization of domesticated varieties with close perennial relatives, most often using crosses between wheat (Triticum L.) and perennial Triticeae from the Thinopyrum genus, could be markedly higher yielding but also experience much lower perenniality and regrowth vigor (Cox et al., 2006; Hayes et al., 2018). Currently, plant breeders are working to improve breeding strategies and agronomic traits of perennial grains, including yield, threshability, favorable phenology, shattering rate, and plant persistence (Cox et al., 2010; DeHaan et al., 2018, 2014, 2005; Hayes et al., 2012; Kantar et al., 2016). In the meantime, one approach to increase feasibility of perennial grains in Western Europe is to focus on multifunctionality and different benefits that perennial grain crops might provide beyond grain production, including forage production, protection of soil resources, regeneration of soil health, conservation of biodiversity, and improvement of agroecosystem resilience (Ryan et al., 2018).

\subsection{Valuation of both grain and forage biomass}


IWG is a cool season crop being developed for both grain and forage production. In contrast to certain crossed lines (x Triticum), IWG produces smaller seeds than annual grains such as wheat (thousand-kernel-weight $=7-8 \mathrm{~g}$ for naked seeds compared to 30-40 $\mathrm{g}$ for winter wheat). To date, breeding efforts have allowed grain yields from 300 to $1500 \mathrm{~kg}$ ha-1 in field experiments and tend to decline over time as the stand fills in and plants become sod bound (Culman et al., 2013; Hayes et al., 2017; Jungers et al., 2017; Pugliese, 2017; Tautges et al., 2018). IWG is also a productive forage crop that can produce biomass comparable to grasslands (e.g., $12 \mathrm{Mg}$ ha-1, Jungers et al., (2017)). Compared with annual cereals, the biomass production is strengthened by the efficient use of solar radiation, nutrients, and water during the post-harvest regrowth (Bell et al., 2008; Cattani and Asselin, 2017). Interestingly, harvesting forage does not cause yield penalties if it is done before stem elongation or after grain harvest (Larkin et al., 2014; Lee et al., 2009; Pugliese, 2017; Pugliese et al., 2019). Higher quality of forage biomass is found in the spring when the relative mass of leaves in regard to stems is the highest (Jungers et al., 2018). But still, post-harvest crop residue has been shown suitable for mature beef cattle feed, which do not need to gain weight during winter. When fed with $50 \%$ of IWG residue, completed by $50 \%$ grass-alfalfa haylage, the average dry matter intake was similar to normal predicted values, with no body condition decrease (Favre, 2019). Considering the economic cost of high quality forage and the strategic objective to match with the dietary need of mature cows, but not to exceed it, IWG postharvest residue could offer a beneficial, low-cost forage source. Thus, managing IWG for both grain and forage production could be a viable option in mixed farming systems. This dual-purpose management and investigation of plant resource allocation to the different plant organs is an active area of research, as there may be different ways to optimize interactions between forage and grain production (Pugliese et al., 2019). For instance, choice in grain harvest method could be made depending either on the optimization of grain yields or crop residue quality (Favre, 2019). When the entire plant is swathed, leaf loss could lower residue forage quality, while direct combining grain could mean heterogeneous grain maturity and losses due to grain shattering. A meta-analysis that examined the performance of different perennial grain genotypes over twenty-one locations across four continents (Hayes et al., 2018), including IWG and perennial wheat derived from $T$. intermedium, suggests that milder climates like in Western Europe, compared with colder climates of higher latitudes such as Northern US and Canada, are favorable for both grain and forage production in the establishment year. In the second and later years of growth, the T. intermedium demonstrated the strongest longevity.

Grain quality is also an important factor dictating economic value. IWG generally expresses an interesting nutritional profile with higher protein, carotenoids, and fiber concentration than in annual wheat (Tyl and Ismail, 2018). While this is mostly the result of a significantly lower ratio of starch (endosperm) compared to bran, the protein composition of the grain is also different, notably including a higher proportion of gliadins and fewer glutenins of high molecular weight producing different bread-making quality (Marti et al., 2016; Tyl and Ismail, 2018; Zhang et al., 2015). Finally, this biomass could also find a useful end as bioenergy feedstock (Jungers et al., 2017; Wang et al., 2014). Similar to perennial bioenergy crops (e.g., switchgrass - Panicum virgatum, miscanthus - Miscanthus sinensis), IWG has several valuable characteristics including its capability of high biomass production and carbohydrate concentration (e.g., hemicellulose), and its ability to grow in various soil and 
climatic conditions (Jungers et al., 2017). Although biomass production is lower than miscanthus (Clifton-Brown et al., 2004), IWG production is comparable to switchgrass, which is currently being grown in Western Europe (Lee et al., 2009; Lewandowski et al., 2003).

\subsection{Promoting soil health, fertility and water quality}

Compared to annual grains, the larger and more persistent root system of perennial grains can have a positive impact on soil health with positive effect on soil porosity, aggregate stability, water infiltration, nutrient cycles and microbial activity (Crews et al., 2016; Crews and Brookes, 2014; Culman et al., 2010; DuPont et al., 2014; Rasche et al., 2017). Water quality can also be improved by transitioning from annual to perennial grain production in sensitive watershed areas. Increased water and nitrogen uptake from soil were observed under IWG, which can prevent leaching and losses due to water runoff, leading to efficient prevention of surface and ground water contamination (Culman et al., 2013; Jungers et al., 2019; Sainju et al., 2017a). Permanent plant cover is also an important lever to increase carbon inputs and storage into soil and to control soil erosion and runoff in sensitive areas (Ryan et al., 2018). Although time is required before increases in soil carbon are detectable and changes are hard to measure in most situations due to strong influence of land management (Necpalova et al., 2014; Sprunger et al., 2017), previous research on IWG and other perennial grasses has shown 12 to 16 times greater root biomass carbon and nitrogen content compared with annual spring wheat and higher levels of carbon and nitrogen in soil compared to other perennial grasses, such as switchgrass and smooth bromegrass - Bromus inermis (Sainju et al., 2017b). Such efficiency of IWG roots for nitrogen uptake is particularly important in a context of limited nitrogen inputs in organic systems or low-input systems (Lasisi et al., 2018). However, additional data will be necessary to understand detailed nitrogen dynamics and determine what happens during crop growth in terms of nitrogen efficiency, and what happens when the crop is tilled in terms of availability, balance and leaching risk. Looking at carbon exchange and balance, de Oliveira et al. (2018) suggest that IWG has good potential as a carbon sink in the long term. This is consistent with the conclusions of Crews and Rumsey (2017) indicating that the conversion from annual to perennial grains could potentially accumulate up to $1.7 \mathrm{t}$ ha-1 year-1 of soil organic carbon. Earlier observations from long-term experiments have indicated also that never-tilled perennial grass fields could maintain over $4 \mathrm{t}$ ha-1 more root carbon and $43 \mathrm{t}$ ha-1 more soil carbon than in annual croplands (Glover et al., 2010). Research is needed to understand the specific and cumulative impacts of IWG and no-till practices on soil health and carbon sequestration across different soil and climate conditions.

\subsection{Control and pest management}

Once well-established, IWG weed competitiveness could be very substantial over its lifetime due to permanent soil cover, light interception, and nutrient use (Dick et al., 2018). Also, the Thinopyrum genus has already been shown responsible for better tolerance or resistance to important plant pathogens, such as fusarium head blight (Li et al., 2017; Mo et al., 2017; Singh et al., 2017). Diversifying perennial grain crops with intercropping or the implementation of insectary strips could further limit the development and spread of crop pests, and be part of an efficient strategy of pest control. Interestingly, the use of crop mixtures could enable different mechanisms including resource dilution, disruption of spatial host density and proximity, or conservation of natural enemies. Of course, farmers may also choose to rotate perennial grains with other annual crops, which could help manage more 
challenging pests. Generally, in spite of attractive perspectives, more investigations and longtime experiments are required to make conclusions about pest issues and identify specific influences and appropriate management strategies. Notably, weed management during the establishment year can be highly challenging as IWG is slow to emerge and does not cover the whole soil surface and has delayed stem elongation and flowering period compared to annual cereal grains (Jungers et al., 2018). This early weed sensitivity may contradict the lowinput purpose since herbicide need could expand during this time. In response, work is currently ongoing to engineer intercrop mowers to allow mechanical weeding or mowing of intercropped legumes. In contrast to fields that have been managed with conventional practices for years, the larger weed-seed bank usually found in organic systems could make IWG establishment particularly sensitive or problematic. Cultural management practices such as altering sowing date, sowing rate, inter-row spacing, and intercropping could contribute to weed suppression in organic cropping systems. Regardless of the management systems, farmers should aim to select fields with low populations of weeds. Differences in farming practices and climate between continental or northern regions of North America and milder climates (oceanic) of Western European countries might result in different weed infestation issues. Like in the case of Alopecurus myosuroides (blackgrass) found in Europe, the capacity to adapt establishment choices and weed control practices would be crucial to deal with a specific weed context and history (Chauvel et al., 2001; Moss, 1980; Moss et al., 2007).

\section{What would fit the Western European context?}

Perennial grains potentially provide answers to existing challenges in Western Europe (e.g., soil erosion control, nitrate leaching reduction), but many challenges still need to be faced before integrating perennial grains into farming systems. Scattered references and "prototypes" like IWG (i.e., crops in development and partially domesticated) are not definitive in tackling the issue of perennial grains use in European agriculture. The development of improved plant materials, including increased grain yields, non-shattering inflorescences and earliness of reproductive stage induction would significantly further perennial grains development and use. To date, no perennial grain is registered in the common seed catalogue in Europe, limiting their use in farm fields. Despite the ease adaptation to existing equipment in fields, questions also remain about their integration and compatibility with existing farming systems. Depending on production priorities, agricultural policy, and market opportunities, farmers might choose to grow perennial grains for a variety of reasons including: (1) environmental goals (water protection, carbon sequestration, maintaining soil health and biodiversity); (2) cropping system strategies (crop diversification, promoting soil fertility, operating costs reduction); and (3) production objectives and value (forage-grain dual use). The delivery and relative benefits of ecosystem services might vary across farms and across fields within farms, and thus spatial placement of perennial grains should be optimized depending on the ecosystem services that are sought (Corry, 2018). 


\subsection{Integration of an adaptive crop in the farmscape}

Figure 4. Designing perennial and annual crops landscape

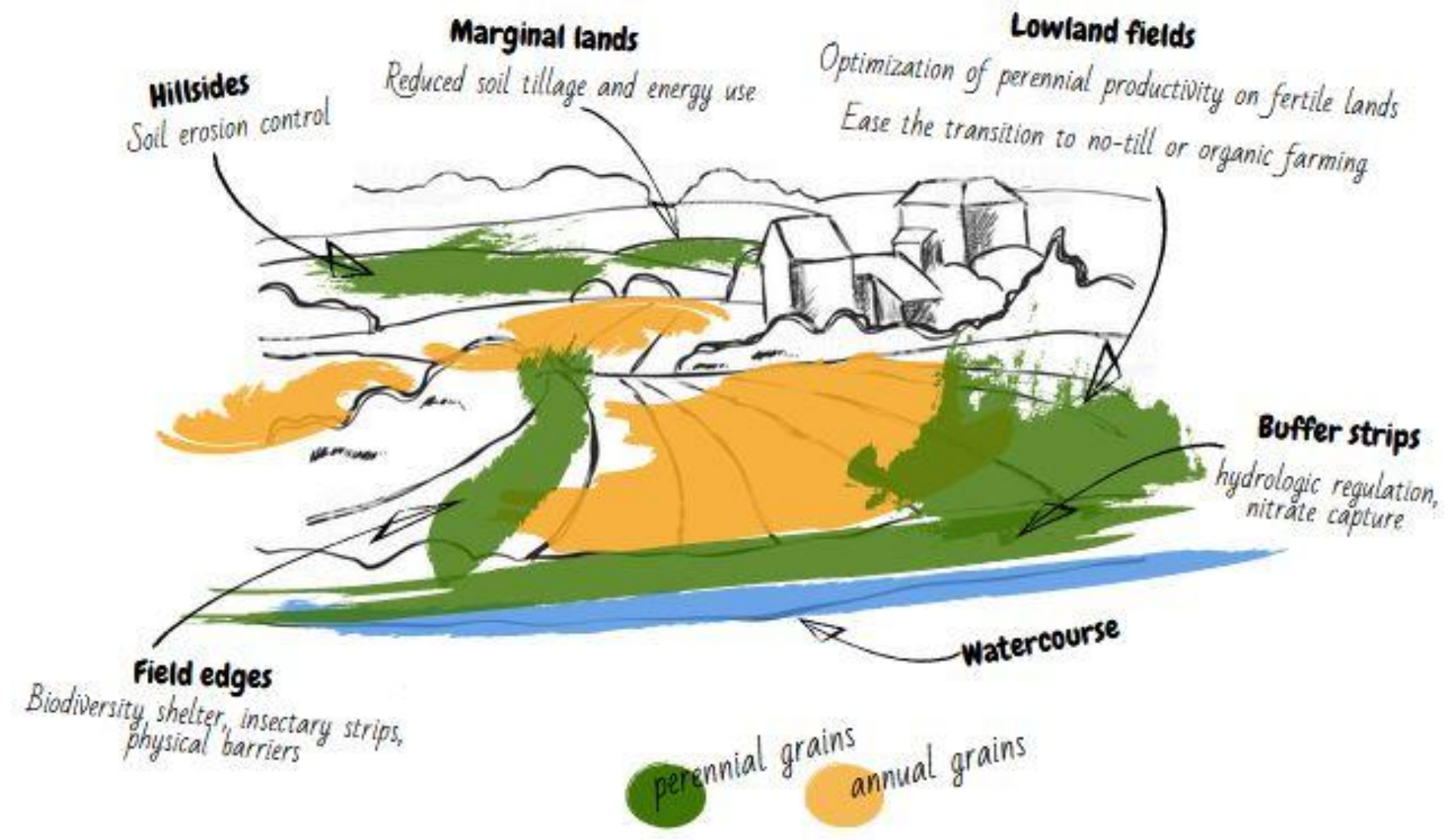

As IWG currently produces lower yields than annual grains, one approach is to focus on strategically integrating this crop in areas where annual grains cause problems, such as on sloped fields with intense soil erosion, marginal lands where potential of production is limited, along field edges to improve functional biodiversity, or as riparian buffers to preserve water quality (Figure 3). This approach could be supported by the hypothesis of Asbjornsen et al., (2014) that suggests there is a 'disproportionate benefit' of including perennials in areas where annual crops are widely grown. Even small areas of perennial grass may provide significant gains (Helmers et al., 2012; Hernandez-Santana et al., 2013; Zhou et al., 2014). For instance, results from Hernandez-Santana et al., (2013) suggest that only $10 \%$ of a field dedicated to prairie strips allows mitigation of most surface runoff, sediment transport and nutrient losses (Cacho et al., 2017). Similarly, Panagos et al. (2015) reported that grass margins and field edges are one of the most significant practices to help in reduction of soil loss, due to their intrinsic efficiency and easy application. Perennial grains also limit soil tillage while providing provisioning services in the form of grain or forage, and thus can be attractive in more productive landscape positions such as lowland crop fields. This would be particularly true in sensitive fields such as watershed protection areas. In contrast to shallow marginal soils, productive lowland fields that have good water reserves, good soil fertility, and that are suitable for machine use would be sought to optimize yields and crop management. Secure plant growth and performance in those favorable lands would also be 
necessary in a context where seed is scarce and farmers are dedicating time to learning a new cropping system.

\subsection{Enhancing services via the duration of the perennial phase in the rotation}

Western European agriculture covers a large range of climatic conditions (from the Scandinavian climate to arid Southern regions, from oceanic contexts to Mediterranean or more continental situations), including all kinds of soils and land profiles. Potential issues of resource depletion (e.g., groundwater recharge), or pest management over illustrate the important need for better identifying suitable growth contexts, productivity objectives and appropriate duration of perennial phases in fields (Bell et al., 2010; Tautges et al., 2018; Vico and Brunsell, 2017; Weißhuhn et al., 2017). Alternating between perennials and annuals will require balancing soil conservation and tillage periods and understanding the magnitude and persistence of services supply depending on the duration of the perennial phase (Ryan et al. 2018). Based on crop-pasture observations, a perennial phase of three years could be worthwhile since gains might arise due to soil fertility improvement (Bell et al., 2010; Franco et al., 2018; Franzluebbers et al., 2014). Soil protection from erosion occurs as soon as plant cover is developed. However, the timing and magnitude of the potential effects on soil compaction and porosity are unclear. Considering carbon sequestration and soil organic carbon gains, no visible improvements can be planned in the short term due to the large influence of many interacting factors, even if increase could be underway (Necpalova et al., 2014; Sprunger et al., 2017; Syswerda et al., 2011; Wander, 2004). However, the periodic use of a perennial phase in the crop rotation will likely improve soil carbon in the long term (Franzluebbers et al., 2014; King and Blesh, 2018), suggesting larger soil carbon gains than carbon losses to the atmosphere during the conversion back to annuals (Grandy and Robertson, 2007). Finally, the assumed increase of root exudation should enable beneficial processes related to soil-plant interactions (e.g., microbial biofertilization or phytostimulation, in Rasche et al., 2017). Within a short time frame (over one or two years), microbial changes are likely to be some of the most visible changes in soil due to perennial roots.

\subsection{European trend for conservation policies and practices}

The last decades have seen the development of new policies and eagerness for agroecological practices in Western Europe. In Threats to Soil Quality in Europe, Montanarella et al. (2008) emphasized how "there has been a surge of concern and attention in Europe to soil degradation processes [...] leading to the adoption by the European Commission in September 2006 of the Thematic Strategy for Soil Protection [...]. One of the most innovative aspects [...] is the recognition of the multifunctionality of soils." The EU Nitrates Directive (1991) and the directive on the sustainable use of pesticides (2009) provide a global framework to promote water, soil and health protection by preventing synthetic input transfers from agricultural sources. These directives mostly imply the monitoring of environmental impacts and the implementation of action programs by the Member States. For instance, the use of extensive practices (e.g., grass margins) in vulnerable riparian and watershed areas has been largely integrated in most of the Member States as an obligation. Under the EU's Common Agricultural Policy (CAP), payments to farmers have been established after 2005 by the Member States in order to promote a set of beneficial agro-environmental practices for Good Agricultural and Environmental Condition (GAEC), such as cover cropping, keeping plant residues, reduced soil tillage, protection of sloping areas and implantation of grass 
margins (Matthews, 2013). These policies do not include perennial grains as yet as they do not exist in European fields but it makes sense to devise soil conservation approaches, including IWG use, as it would fulfill many current requirements (soil cover, reduced soil tillage, protection of sensitive areas). The expansion of organic and conservation practices in European farming systems are also demonstrating how farmers seek new means to move forward in farming sustainability. In 2016, more than 12 million European hectares were under organic farming (Le Douarin, 2017) and the development of conservation practices is also expressing a net upward trend. Four hundred thousand hectares were managed by conservation practices in France in 2001 and rose to 630,000 hectares in 2006. As a consequence, the share of no-till cereal crop systems has increased from $21 \%$ to $34 \%$ during the same period (Schaller, 2013). Notwithstanding that the adoption of organic or conservation practices are likely to be related to economic reasons in one way or another (Napier, 2010), environmental concerns and specific soil care are increasingly becoming part of the decision process (Casagrande et al., 2016; Peigné et al., 2016; Wilson and Hart, 2000). But the current absence of a European market, value chain and economic references for perennial grains is actually hindering the informed process of balancing incentives and disincentives that should finally lead to farmer choice, strategy and crop profitability.

\subsection{A springboard to perennial grains}

Given the recent changes and trends in EU land management, it is likely that perennial grains will be valued for their effects on soil and water quality. Providing farmers with incentives based on valuable services coming from perennials at the farm (soil fertility) or society level (water quality, climate change mitigation), while their cultivation could agree with EU Directives (nitrates or pesticides), would allow the restoration of "unproductive" vulnerable and restricted areas (e.g., watershed or riparian zones) to grain-forage production fields. This should not promote the conversion of native vegetation or wildlands, but allow for production of perennial fields in sensitive or unprofitable areas for annual grain production. This would shift the issue of grain yield reduction compared to annual counterparts, to the opportunity of additional grain production permitted by perennial grains. Also, one current use for IWG could be as a transitional crop from conventional to organic production. In order to combine the benefits of weed management history of conventional fields and the willingness to promote organic practices and reduced chemical use, growing IWG on transitional fields, either conventional or organic, could make sense. The same logic should also apply to new fields managed with no or reduced tillage where the transition period could result in soil compaction increase (Peigné et al., 2018; Vian et al., 2009). The benefit of year-round cover and deep rooted grain plants would also make IWG a strategical transitional crop.

\subsection{Restore mixed farming and grasslands value}

Both organic and conservation systems have potential for integration of perennial grains. Market variations, volatile prices and production costs due to input use are endangering the profitability of a large set of farming systems, especially conventional systems using high inputs, since the calculation of their gross margins over years could suffer from chronic reductions (Pacini et al., 2003; Pimentel et al., 2005). Valuing ecosystem services and harvesting both grain and forage from perennial grain systems enhances the economic outlook for these new systems. The opportunity of grain-forage dual-use management of IWG makes mixed (crop-livestock) systems naturally privileged. The forage biomass will find use for 
animal feeding, as could the grain even if use in the human diet would bring additional economic value. This adaptability to produce both grain and forage also offers valuable plasticity in fields to respond to yearly variability and hazards in terms of climatic conditions, plant performances or market opportunities. Current concerns about climatic changes, repeated drought periods and earlier ending of the growing seasons increases forage demand for self-sufficiency and influence farming strategies to strengthen farm adaptability (Chang et al., 2017; Lurette et al., 2013; Nettier et al., 2010; Volaire et al., 2014). Dealing with this issue, the IWG production of forage biomass at summer or during post-harvest regrowth represents a strong asset and value. As the current absence of truly perennial grain which maintains grain yields over years, the IWG model suggests a climax grain production the first harvested years (Tautges et al., 2018) and then declines due to changes in the availability and/or allocation of resources, or lack of persistence and over-wintering. Thus, the dual-use purpose could also be considered on a multiyear basis, taking profits either from grain or forage depending on what is worth more. However, the importance of mixed farming in Western European countries (crop and livestock) is significantly lower than arable croplands, and has been decreasing. In France, the 2010 agricultural census indicated that only $13 \%$ of the French agricultural holdings, and only $16 \%$ of the agricultural lands, are involved in mixed farming, while arable croplands account for 35\% (Agreste, 2010). Due to this specialization, the conservation of grass fields that help in maintaining ecological functions is arduous. Less than $15 \%$ of the total European land is dedicated to grass fields. The decline in grasslands is due to their lack of revenue relative to staple crop production in the context of intensification and productive agriculture development. Bypassing or limiting the gap between grain and forage field profits, perennial grains have potential to help reverse this trend if they can increase the economic returns from perennial grass/legume fields.

\section{Conclusion}

The tremendous interest in perennial grains that is growing in many places has not yet fully transformed into research or practical applications in Western Europe. This makes it difficult to couple perennial grains progress to local farming systems opportunities. The introduction of new crops for the purpose of diversification and a new economic scenario has already been suggested either in North America or Europe, and includes many different crops (e.g., quinoa, hemp, buckwheat, miscanthus, switchgrass, etc.; Krupinsky et al., 2002; Mudgal et al., 2010). But the introduction of perennial grains would provide an unprecedented opportunity to better value grasslands from combining forage and environmental conservation with the production of high value grains. However, farmer adoption of innovative and transformative practices is an interactive and multifactorial process. The preconditions for such adoption have been gathered within a four imperative measures process, including: 1) farmer willingness and motivation; 2) an existing demand; 3) farmer's ability to implement the new practice; and 4) the legitimation or recognition of the practice (Runhaar, 2017; Schoonhoven and Runhaar, 2018). Despite that we have seen the current expansion and eagerness from farmers to society for sustainable development of agriculture, perennial grains are not legitimized yet by agricultural standards and policies. The reality and rapidity of the increase in yield through breeding, the availability of seed and the creation of value chains will define the accuracy of perennial grains adoption and legitimization. While there is no market demand in Europe yet, the investment and food processing from US companies such as General Mills or Patagonia Provisions are encouraging signs of the emerging value of perennial grains in Western 
Europe. In the meantime, important knowledge gaps need to be filled to establish and deepen perennial grain research in Western Europe. As prime research areas to determine relevant farming situations for perennial grains integration, we suggest 1) quantifying growth and performance under different soil and climate conditions; 2) characterizing the environmental gains and tangible benefits in relation with plant age and duration in field; 3) developing basic field management guidelines and techniques; 4) identifying best-case scenarios for perennial grains use in terms of purposes, locations, and coherent farming systems; 5) characterizing food and feed value to evaluate global crop economics; and 6) setting up European breeding and selection programs in order to provide materials adapted to European conditions. 


\section{References}

Adebiyi, J., Schmitt Olabisi, L., Snapp, S., 2016. Understanding perennial wheat adoption as a transformative technology: evidence from the literature and farmers. Renew. Agric. Food Syst. 31, 101-110. https://doi.org/10.1017/S1742170515000150

Agreste, 2018. Bilan annuel $2017 \quad$ [WWW $\quad$ Document]. http://agreste.agriculture.gouv.fr/IMG/pdf/R2418A10.pdf (accessed 3.24.19).

Agreste, 2010. Recensement agricole 2010 : exploitations agricoles et superficie agricole utilisée par orientation technico-économique [WWW Document]. URL http://agreste.agriculture.gouv.fr/recensementagricole-2010/resultats-donnees-chiffrees/ (accessed 10.25.18).

Asbjornsen, H., Hernandez-Santana, V., Liebman, M., Bayala, J., Chen, J., Helmers, M., Ong, C.K., Schulte, L.A., 2014. Targeting perennial vegetation in agricultural landscapes for enhancing ecosystem services. Renew. Agric. Food Syst. 29, 101-125. https://doi.org/10.1017/S1742170512000385

Bell, L.W., Byrne (nee Flugge), F., Ewing, M.A., Wade, L.J., 2008. A preliminary whole-farm economic analysis of perennial wheat in an Australian dryland farming system. Agric. Syst. 96, 166-174. https://doi.org/10.1016/j.agsy.2007.07.007

Bell, L.W., Wade, L.J., Ewing, M.A., 2010. Perennial wheat: a review of environmental and agronomic prospects for development in Australia. Crop Pasture Sci. 61, 679. https://doi.org/10.1071/CP10064

Cacho, J.F., Negri, M.C., Zumpf, C.R., Campbell, P., 2017. Introducing perennial biomass crops into agricultural landscapes to address water quality challenges and provide other environmental services: Integrating perennial bioenergy crops into agricultural landscapes. Wiley Interdiscip. Rev. Energy Environ. e275. https://doi.org/10.1002/wene.275

Casagrande, M., Peigné, J., Payet, V., Mäder, P., Sans, F.X., Blanco-Moreno, J.M., Antichi, D., Bàrberi, P., Beeckman, A., Bigongiali, F., Cooper, J., Dierauer, H., Gascoyne, K., Grosse, M., Heß, J., Kranzler, A., Luik, A., Peetsmann, E., Surböck, A., Willekens, K., David, C., 2016. Organic farmers' motivations and challenges for adopting conservation agriculture in Europe. Org. Agric. 6, 281-295. https://doi.org/10.1007/s13165-015-0136-0

Cattani, D., Asselin, S.R., 2017. Extending the Growing Season: Forage Seed Production and Perennial Grains. Can. J. Plant Sci. https://doi.org/10.1139/CJPS-2017-0212

Chang, J., Ciais, P., Viovy, N., Soussana, J.-F., Klumpp, K., Sultan, B., 2017. Future productivity and phenology changes in European grasslands for different warming levels: implications for grassland management and carbon balance. Carbon Balance Manag. 12, 11. https://doi.org/10.1186/s13021-017-0079-8

Chauvel, B., Guillemin, J.P., Colbach, N., Gasquez, J., 2001. Evaluation of cropping systems for management of herbicide-resistant populations of blackgrass (Alopecurus myosuroides Huds.). Crop Prot. 20, 127-137. https://doi.org/10.1016/S0261-2194(00)00065-X

Clifton-brown John C., Stampfl Paul F., Jones Michael B., 2004. Miscanthus biomass production for energy in Europe and its potential contribution to decreasing fossil fuel carbon emissions. Glob. Change Biol. 10, 509-518. https://doi.org/10.1111/j.1529-8817.2003.00749.x

Corry, R.C., 2018. Designed strategic redeployment of perennial cover in North American farm landscapes. J. Soil Water Conserv. 73, 132A-139A. https://doi.org/10.2489/jswc.73.5.132A

Cox, T.S., Glover, J.D., Tassel, V., L, D., Cox, C.M., DeHaan, L.R., 2006. Prospects for Developing Perennial Grain Crops. BioScience 56, 649-659. https://doi.org/10.1641/0006-3568(2006)56[649:PFDPGC]2.0.CO;2

Cox, T.S., Van Tassel, D.L., Cox, C.M., DeHaan, L.R., 2010. Progress in breeding perennial grains. Crop Pasture Sci. 61, 513. https://doi.org/10.1071/CP09201

Crews, T.E., Blesh, J., Culman, S.W., Hayes, R.C., Jensen, E.S., Mack, M.C., Peoples, M.B., Schipanski, M.E., 2016. Going where no grains have gone before: From early to mid-succession. Agric. Ecosyst. Environ. 223, 223-238. https://doi.org/10.1016/j.agee.2016.03.012

Crews, T.E., Brookes, P.C., 2014. Changes in soil phosphorus forms through time in perennial versus annual agroecosystems. Agric. Ecosyst. Environ. 184, 168-181. https://doi.org/10.1016/j.agee.2013.11.022

Crews, T.E., Peoples, M.B., 2005. Can the Synchrony of Nitrogen Supply and Crop Demand be Improved in Legume and Fertilizer-based Agroecosystems? A Review. Nutr. Cycl. Agroecosystems 72, 101-120. https://doi.org/10.1007/s10705-004-6480-1

Crews, T.E., Rumsey, B., 2017. What Agriculture Can Learn from Native Ecosystems in Building Soil Organic Matter: A Review. Sustainability 9, 578. https://doi.org/10.3390/su9040578

Culman, S.W., DuPont, S.T., Glover, J.D., Buckley, D.H., Fick, G.W., Ferris, H., Crews, T.E., 2010. Long-term impacts of high-input annual cropping and unfertilized perennial grass production on soil properties 
and belowground food webs in Kansas, USA. Agric. Ecosyst. Environ. 137, 13-24. https://doi.org/10.1016/j.agee.2009.11.008

Culman, S.W., Snapp, S.S., Ollenburger, M., Basso, B., DeHaan, L.R., 2013. Soil and Water Quality Rapidly Responds to the Perennial Grain Kernza Wheatgrass. Agron. J. 105, 735. https://doi.org/10.2134/agronj2012.0273

De Oliveira, G., Brunsell, N.A., Sutherlin, C.E., Crews, T.E., DeHaan, L.R., 2018. Energy, water and carbon exchange over a perennial Kernza wheatgrass crop. Agric. For. Meteorol. 249, 120-137. https://doi.org/10.1016/j.agrformet.2017.11.022

DeHaan, L., Christians, M., Crain, J., Poland, J., 2018. Development and Evolution of an Intermediate Wheatgrass Domestication Program. Sustainability 10, 1499. https://doi.org/10.3390/su10051499

DeHaan, L.R., Ismail, B.P., 2017. Perennial Cereals Provide Ecosystem Benefits. Cereal Foods World 62, 278281. https://doi.org/10.1094/CFW-62-6-0278

DeHaan, L.R., Van Tassel, D.L., Cox, T.S., 2005. Perennial grain crops: A synthesis of ecology and plant breeding. Renew. Agric. Food Syst. 20, 5-14. https://doi.org/10.1079/RAF200496

DeHaan, L.R., Wang, S., Larson, S., Cattani, D., Zhang, X., Kantarski, T., 2014. Current efforts to develop perennial wheat and domesticate Thinopyrum intermedium. Perenn. CROPS FOOD Secur. 72.

Dick, C., Cattani, D., Entz, M., 2018. Kernza Intermediate wheatgrass (Thinopyrum intermedium) grain production as influenced by legume intercropping and residue management. Can. J. Plant Sci. 98, 1376-1379.

DuPont, S.T., Beniston, J., Glover, J.D., Hodson, A., Culman, S.W., Lal, R., Ferris, H., 2014. Root traits and soil properties in harvested perennial grassland, annual wheat, and never-tilled annual wheat. Plant Soil 381, 405-420. https://doi.org/10.1007/s11104-014-2145-2

Eurostat, 2018. Crop production in EU [WWW Document]. URL http://appsso.eurostat.ec.europa.eu/nui/show.do?dataset=apro_cpshr\&lang=en (accessed 10.8.18).

Favre, J.R., 2019. Effect of harvest timing on forage yield and nutritive value of annual and perennial grain and forage crops: oat and Kernza intermediate wheatgrass. Wisconsin-Madison.

FranceAgriMer, 2012. Variétés et rendement descéréales biologiques.

Franco, J.G., Duke, S.E., Hendrickson, J.R., Liebig, M.A., Archer, D.W., Tanaka, D.L., 2018. Spring Wheat Yields Following Perennial Forages in a Semiarid No-Till Cropping System. Agron. J. $0,0$. https://doi.org/10.2134/agronj2018.01.0072

Franzluebbers, A.J., Sawchik, J., Taboada, M.A., 2014. Agronomic and environmental impacts of pasture-crop rotations in temperate North and South America. Agric. Ecosyst. Environ. 190, 18-26. https://doi.org/10.1016/j.agee.2013.09.017

Glover, J.D., Culman, S.W., DuPont, S.T., Broussard, W., Young, L., Mangan, M.E., Mai, J.G., Crews, T.E., DeHaan, L.R., Buckley, D.H., 2010. Harvested perennial grasslands provide ecological benchmarks for agricultural sustainability. Agric. Ecosyst. Environ. 137, 3-12. https://doi.org/10.1016/j.agee.2009.11.001

Grandy, A.S., Robertson, G.P., 2007. Land-Use Intensity Effects on Soil Organic Carbon Accumulation Rates and Mechanisms. Ecosystems 10, 59-74. https://doi.org/10.1007/s10021-006-9010-y

Hayes, R., Wang, S., Newell, M., Turner, K., Larsen, J., Gazza, L., Anderson, J., Bell, L., Cattani, D., Frels, K., Galassi, E., Morgounov, A., Revell, C., Thapa, D., Sacks, E., Sameri, M., Wade, L., Westerbergh, A., Shamanin, V., Amanov, A., Li, G., 2018. The Performance of Early-Generation Perennial Winter Cereals at 21 Sites across Four Continents. Sustainability 10, 1124. https://doi.org/10.3390/su10041124

Hayes, R.C., Newell, M.T., Crews, T.E., Peoples, M.B., 2017. Perennial cereal crops: An initial evaluation of wheat derivatives grown in mixtures with a regenerating annual legume. Renew. Agric. Food Syst. 32, 276-290. https://doi.org/10.1017/S1742170516000260

Hayes, R.C., Newell, M.T., DeHaan, L.R., Murphy, K.M., Crane, S., Norton, M.R., Wade, L.J., Newberry, M., Fahim, M., Jones, S.S., Cox, T.S., Larkin, P.J., 2012. Perennial cereal crops: An initial evaluation of wheat derivatives. Field Crops Res. 133, 68-89. https://doi.org/10.1016/j.fcr.2012.03.014

Helmers, M.J., Zhou, X., Asbjornsen, H., Kolka, R., Tomer, M.D., Cruse, R.M., 2012. Sediment Removal by Prairie Filter Strips in Row-Cropped Ephemeral Watersheds. J. Environ. Qual. 41, 1531. https://doi.org/10.2134/jeq2011.0473

Hernandez-Santana, V., Zhou, X., Helmers, M.J., Asbjornsen, H., Kolka, R., Tomer, M., 2013. Native prairie filter strips reduce runoff from hillslopes under annual row-crop systems in lowa, USA. J. Hydrol. 477, 94103. https://doi.org/10.1016/j.jhydrol.2012.11.013 
Jungers, J.M., DeHaan, L.H., Mulla, D.J., Sheaffer, C.C., Wyse, D.L., 2019. Reduced nitrate leaching in a perennial grain crop compared to maize in the Upper Midwest, USA. Agric. Ecosyst. Environ. 272, 63-73. https://doi.org/10.1016/j.agee.2018.11.007

Jungers, J.M., DeHaan, L.R., Betts, K.J., Sheaffer, C.C., Wyse, D.L., 2017. Intermediate Wheatgrass Grain and Forage Yield Responses to Nitrogen Fertilization. Agron. J. 109, 462-472. https://doi.org/10.2134/agronj2016.07.0438

Jungers, J.M., Frahm, C.S., Tautges, N.E., Ehlke, N.J., Wells, M.S., Wyse, D.L., Sheaffer, C.C., 2018. Growth, development, and biomass partitioning of the perennial grain crop Thinopyrum intermedium: Growth, development, and biomass partitioning of a perennial grain crop. Ann. Appl. Biol. https://doi.org/10.1111/aab.12425

Kantar, M.B., Tyl, C.E., Dorn, K.M., Zhang, X., Jungers, J.M., Kaser, J.M., Schendel, R.R., Eckberg, J.O., Runck, B.C., Bunzel, M., Jordan, N.R., Stupar, R.M., Marks, M.D., Anderson, J.A., Johnson, G.A., Sheaffer, C.C., Schoenfuss, T.C., Ismail, B., Heimpel, G.E., Wyse, D.L., 2016. Perennial Grain and Oilseed Crops. Annu. Rev. Plant Biol. 67, 703-729. https://doi.org/10.1146/annurev-arplant-043015-112311

King, A.E., Blesh, J., 2018. Crop rotations for increased soil carbon: perenniality as a guiding principle. Ecol. Appl. 28, 249-261. https://doi.org/10.1002/eap.1648

Krupinsky, J.M., Bailey, K.L., McMullen, M.P., Gossen, B.D., Turkington, T.K., 2002. Managing Plant Disease Risk in Diversified Cropping Systems. Agron. J. 94, 198-209. https://doi.org/10.2134/agronj2002.1980

Larkin, P.J., Newell, M.T., Hayes, R.C., Aktar, J., Norton, M.R., Moroni, S.J., Wade, L.J., 2014. Progress in developing perennial wheats for grain and grazing. Crop Pasture Sci. 65, 1147-1164. https://doi.org/10.1071/CP13330

Lasisi, A.A., Akinremi, O.O., Tenuta, M., Cattani, D., 2018. Below-ground plant biomass and nitrogen uptake of perennial forage grasses and annual crops fertilized with pig manures. Agric. Ecosyst. Environ. 268, 17. https://doi.org/10.1016/j.agee.2018.08.006

Le Douarin, S., 2017. Le Bio dans l'Union Européenne, Les Carnets de l'Agence Bio. ed. Agence Bio.

Lee, D., Owens, V.N., Boe, A., Koo, B.-C., 2009. Biomass and seed yields of big bluestem, switchgrass, and intermediate wheatgrass in response to manure and harvest timing at two topographic positions. GCB Bioenergy 1, 171-179. https://doi.org/10.1111/j.1757-1707.2009.01008.x

Lewandowski, I., Scurlock, J.M.O., Lindvall, E., Christou, M., 2003. The development and current status of perennial rhizomatous grasses as energy crops in the US and Europe. Biomass Bioenergy 25, 335-361. https://doi.org/10.1016/S0961-9534(03)00030-8

Li, X., Jiang, X., Chen, X., Song, J., Ren, C., Xiao, Y., Gao, X., Ru, Z., 2017. Molecular cytogenetic identification of a novel wheat-Agropyron elongatum chromosome translocation line with powdery mildew resistance. PLOS ONE 12, e0184462. https://doi.org/10.1371/journal.pone.0184462

Lurette, A., Aubron, C., Moulin, C.-H., 2013. A simple model to assess the sensitivity of grassland dairy systems to scenarios of seasonal biomass production variability. Comput. Electron. Agric. 93, 27-36. https://doi.org/10.1016/j.compag.2013.01.008

Marti, A., E Bock, J., Pagani, M., Ismail, B., Seetharaman, K., 2016. Structural characterization of proteins in wheat flour doughs enriched with intermediate wheatgrass (Thinopyrum intermedium) flour. Food Chem. 194, 994-1002. https://doi.org/10.1016/j.foodchem.2015.08.082

Matthews, A., 2013. Greening agricultural payments in the EU's Common Agricultural Policy. Bio-Based Appl. Econ. 2, 1-27-27. https://doi.org/10.13128/BAE-12179

Michon, J., 2016. Concentrations en nitrates d'origine agricole dans les cours d'eau et les eaux souterraines (données 2014-2015).

Mo, Q., Wang, C. y., Chen, C. h., Wang, Y. j., Zhang, H., Liu, X. I., Ji, W. q., 2017. Molecular cytogenetic identification of a wheat-Thinopyrum ponticum substitution line with stripe rust resistance. Cereal Res. Commun. 45, 564-573. https://doi.org/10.1556/0806.45.2017.037

Montanarella, L., Rusco, E., Tóth, G., European Commission, Joint Research Centre, Institute for Environment and Sustainability, 2008. Threats to soil quality in Europe. Publications Office, Luxembourg.

Moss, S.R., 1980. The agro-ecology and control of black-grass, Alopecurus myosuroides Huds., in modern cereal growing systems. ADAS Q. Rev. 170-191.

Moss, S.R., Perryman, S.A.M., Tatnell, L.V., 2007. Managing Herbicide-resistant Blackgrass (Alopecurus myosuroides): Theory and Practice. Weed Technol. 21, 300-309. https://doi.org/10.1614/WT-06087.1

Mudgal, S., Lavelle, P., Cachia, F., Somogyi, D., Majewski, E., Fontaine, L., Bechini, L., Debaeke, P., 2010. Environmental impacts of different crop rotations in the european union. European comission. 
Napier, T.L. (Ed.), 2010. Human dimensions of soil and water conservation: a global perspective. Nova Science Publishers, New York.

Necpalova, M., Anex, R.P., Kravchenko, A.N., Abendroth, L.J., Del Grosso, S.J., Dick, W.A., Helmers, M.J., Herzmann, D., Lauer, J.G., Nafziger, E.D., Sawyer, J.E., Scharf, P.C., Strock, J.S., Villamil, M.B., 2014. What does it take to detect a change in soil carbon stock? A regional comparison of minimum detectable difference and experiment duration in the north central United States. J. Soil Water Conserv. 69, 517-531. https://doi.org/10.2489/jswc.69.6.517

Nettier, B., Dobremez, L., Coussy, J.-L., Romagny, T., 2010. Attitudes of livestock farmers and sensitivity of livestock farming systems to drought conditions in the French Alps. J. Alp. Res. Rev. Géographie Alp. https://doi.org/10.4000/rga.1307

Pacini, C., Wossink, A., Giesen, G., Vazzana, C., Huirne, R., 2003. Evaluation of sustainability of organic, integrated and conventional farming systems: a farm and field-scale analysis. Agric. Ecosyst. Environ. 95, 273-288. https://doi.org/10.1016/S0167-8809(02)00091-9

Panagos, P., Borrelli, P., Poesen, J., Ballabio, C., Lugato, E., Meusburger, K., Montanarella, L., Alewell, C., 2015. The new assessment of soil loss by water erosion in Europe. Environ. Sci. Policy 54, 438-447. https://doi.org/10.1016/j.envsci.2015.08.012

Peigné, J., Casagrande, M., Payet, V., David, C., Sans, F.X., Blanco-Moreno, J.M., Cooper, J., Gascoyne, K., Antichi, D., Bàrberi, P., Bigongiali, F., Surböck, A., Kranzler, A., Beeckman, A., Willekens, K., Luik, A., Matt, D., Grosse, M., Heß, J., Clerc, M., Dierauer, H., Mäder, P., 2016. How organic farmers practice conservation agriculture in Europe. Renew. Agric. Food Syst. 31, 72-85. https://doi.org/10.1017/S1742170514000477

Peigné, J., Vian, J.-F., Payet, V., Saby, N.P.A., 2018. Soil fertility after 10 years of conservation tillage in organic farming. Soil Tillage Res. 175, 194-204. https://doi.org/10.1016/j.still.2017.09.008

Pimentel, D., Hepperly, P., Hanson, J., Douds, D., Seidel, R., 2005. Environmental, Energetic, and Economic Comparisons of Organic and Conventional Farming Systems. BioScience 55, 573. https://doi.org/10.1641/0006-3568(2005)055[0573:EEAECO]2.0.CO;2

Power, A.G., 2010. Ecosystem services and agriculture: tradeoffs and synergies. Philos. Trans. R. Soc. Lond. B Biol. Sci. 365, 2959-2971. https://doi.org/10.1098/rstb.2010.0143

Pugliese, J.Y., 2017. Above-and Belowground Response to Managing Kernza (Thinopyrum intermedium) as a Dual-Use Crop for Forage and Grain. The Ohio State University.

Pugliese, J.Y., Culman, S.W., Sprunger, C.D., 2019. Harvesting forage of the perennial grain crop kernza (Thinopyrum intermedium) increases root biomass and soil nitrogen cycling. Plant Soil. https://doi.org/10.1007/s11104-019-03974-6

Rasche, F., Blagodatskaya, E., Emmerling, C., Belz, R., Musyoki, M.K., Zimmermann, J., Martin, K., 2017. A preview of perennial grain agriculture: knowledge gain from biotic interactions in natural and agricultural ecosystems. Ecosphere 8, n/a-n/a. https://doi.org/10.1002/ecs2.2048

Runhaar, H., 2017. Governing the transformation towards 'nature-inclusive' agriculture: insights from the Netherlands. Int. J. Agric. Sustain. 15, 340-349. https://doi.org/10.1080/14735903.2017.1312096

Ryan, M.R., Crews, T.E., Culman, S.W., DeHaan, L.R., Hayes, R.C., Jungers, J.M., Bakker, M.G., 2018. Managing for Multifunctionality in Perennial Grain Crops 11.

Sainju, U.M., Allen, B.L., Lenssen, A.W., Ghimire, R.P., 2017a. Root biomass, root/shoot ratio, and soil water content under perennial grasses with different nitrogen rates. Field Crops Res. 210, 183-191. https://doi.org/10.1016/j.fcr.2017.05.029

Sainju, U.M., Allen, B.L., Lenssen, A.W., Mikha, M., 2017b. Root and soil total carbon and nitrogen under bioenergy perennial grasses with various nitrogen rates. Biomass Bioenergy 107, 326-334. https://doi.org/10.1016/j.biombioe.2017.10.021

Schaller, N., 2013. L'agriculture de conservation.

Schoonhoven, Y., Runhaar, H., 2018. Conditions for the adoption of agro-ecological farming practices: a holistic framework illustrated with the case of almond farming in Andalusia. Int. J. Agric. Sustain. 16, 442-454. https://doi.org/10.1080/14735903.2018.1537664

Singh, M., Mallick, N., Chand, S., Kumari, P., Sharma, J.B., Sivasamy, M., Jayaprakash, P., Prabhu, K.V., Jha, S.K., Vinod, 2017. Marker-assisted pyramiding of Thinopyrum-derived leaf rust resistance genes Lr19 and Lr24 in bread wheat variety HD2733. J. Genet. 96, 951-957. https://doi.org/10.1007/s12041-0170859-7

Sprunger, C.D., Culman, S.W., Robertson, G.P., Snapp, S.S., 2017. Perennial grain on a Midwest Alfisol shows no sign of early soil carbon gain. Renew. Agric. Food Syst. 1-13. https://doi.org/10.1017/S1742170517000138 
Syswerda, S.P., Corbin, A.T., Mokma, D.L., Kravchenko, A.N., Robertson, G.P., 2011. Agricultural Management and Soil Carbon Storage in Surface vs. Deep Layers. Soil Sci. Soc. Am. J. 75, 92-101. https://doi.org/10.2136/sssaj2009.0414

Tautges, N.E., Jungers, J.M., DeHaan, L.R., Wyse, D.L., Sheaffer, C.C., 2018. Maintaining grain yields of the perennial cereal intermediate wheatgrass in monoculture $\mathrm{v}$. bi-culture with alfalfa in the Upper Midwestern USA. J. Agric. Sci. 1-16. https://doi.org/10.1017/S0021859618000680

Tyl, C., Ismail, B.P., 2018. Compositional evaluation of perennial wheatgrass ( Thinopyrum intermedium ) breeding populations. Int. J. Food Sci. Technol. https://doi.org/10.1111/ijfs.13925

Vian, J.F., Peigne, J., Chaussod, R., Roger-Estrade, J., 2009. Effects of four tillage systems on soil structure and soil microbial biomass in organic farming. Soil Use Manag. 25, 1-10. https://doi.org/10.1111/j.14752743.2008.00176.x

Vico, G., Brunsell, N.A., 2017. Tradeoffs between water requirements and yield stability in annual vs. perennial crops. Adv. Water Resour. 112, 189-202. https://doi.org/10.1016/j.advwatres.2017.12.014

Volaire, F., Barkaoui, K., Norton, M., 2014. Designing resilient and sustainable grasslands for a drier future: Adaptive strategies, functional traits and biotic interactions. Eur. J. Agron. 52, 81-89. https://doi.org/10.1016/j.eja.2013.10.002

Wander, M., 2004. Soil Organic Matter Fractions and Their Relevance to Soil Function, in: Magdoff, F., Weil, R. (Eds.), Soil Organic Matter in Sustainable Agriculture. CRC Press. https://doi.org/10.1201/9780203496374.ch3

Wang, G.-J., Nyren, P., Xue, Q.-W., Aberle, E., Eriksmoen, E., Tjelde, T., Liebig, M., Nichols, K., Nyren, A., 2014. Establishment and Yield of Perennial Grass Monocultures and Binary Mixtures for Bioenergy in North Dakota. Agron. J. 106, 1605-1613. https://doi.org/10.2134/agronj14.0068

Weißhuhn, P., Reckling, M., Stachow, U., Wiggering, H., 2017. Supporting Agricultural Ecosystem Services through the Integration of Perennial Polycultures into Crop Rotations. Sustainability 9, 2267. https://doi.org/10.3390/su9122267

Wilson, G.A., Hart, K., 2000. Financial Imperative or Conservation Concern? EU Farmers' Motivations for Participation in Voluntary Agri-Environmental Schemes. Environ. Plan. Econ. Space 32, 2161-2185. https://doi.org/10.1068/a3311

Zhang, X., Ohm, J.-B., Haring, S., DeHaan, L.R., Anderson, J.A., 2015. Towards the understanding of end-use quality in intermediate wheatgrass (Thinopyrum intermedium): High-molecular-weight glutenin subunits, protein polymerization, and mixing characteristics. J. Cereal Sci. 66, 81-88. https://doi.org/10.1016/j.jcs.2015.10.008

Zhou, X., Helmers, M.J., Asbjornsen, H., Kolka, R., Tomer, M.D., Cruse, R.M., 2014. Nutrient removal by prairie filter strips in agricultural landscapes. J. Soil Water Conserv. 69, 54-64. https://doi.org/10.2489/jswc.69.1.54 